\title{
Saccate thallus of the red alga Halosaccion glandiforme harbor diverse invertebrate fauna
}

\author{
Ritindra N. Bhaduri · Maya Wolf
}

Received: 10 December 2016/Accepted: 18 April 2017/Published online: 27 April 2017

(C) The Author(s) 2017. This article is an open access publication

\begin{abstract}
Rocky intertidal zones are biologically diverse environments with numerous physical stressors; as such, close associations between organisms often develop to overcome such stressors and enhance survival of associates. As major components of rocky shores, macroalgae support numerous invertebrate species. In this study, we evaluated the habitat-providing role of the red alga, Halosaccion glandiforme (S.G. Gmelin) Ruprecht. This alga, also called sea sacs, is commonly found on rocky shores along the West Coast of North America. During emersion, this seaweed holds water within its saccate thallus, which can potentially serve as microhabitat for various organisms. Little is known about the composition of microfauna associated with this seaweed; as such, we documented richness and abundance of species found inside its thallus. Algal specimens were collected from Charleston, Oregon and transported to the laboratory for further analyses. Of the 119 thalli examined, 12 taxa were documented. Nematodes and copepods were the dominant taxa. Other groups represented included ostracods, turbellarians, halacarid mites, bivalves, rotifers, and three larval types (barnacle cyprids, copepod nauplii, mollusc veliger). Diatoms, crustacean molt remnants, detritus, and sand particles were also observed inside thalli. Species richness and abundance were positively correlated with thalli volume, as well as intra-thalli fluid volume. Several feeding and other behaviors of colonizers were noted; they included herbivory, predator-prey interactions, detritivory, and molting. Our findings demonstrate that $H$. glandiforme provide refuge for organisms from harsh environmental conditions during emersion periods, and also serve as feeding and nursery grounds for its diverse invertebrate fauna.
\end{abstract}

Keywords Sea sacs · Microhabitat · Invertebrate composition · Rocky intertidal community

\section{Introduction}

Rocky shores are dynamic environments inhabited by organisms that are able to withstand harsh abiotic and biotic conditions. Some of these organisms, especially macroalgae, provide habitats for many benthic species. These species depend on the physical structure and other resources provided by the seaweeds, thereby enhancing their survival and increasing diversity and abundance (Lilley and Schiel 2006; Wikström and Kautsky 2007).

R. N. Bhaduri $(\square)$

Department of Biological Sciences, California State University Stanislaus, One University Circle, Turlock, CA 95382, USA

e-mail: rbhaduri@csustan.edu

M. Wolf

Oregon Institute of Marine Biology, University of Oregon, Charleston, OR 97420, USA

e-mail: mwolf1@uoregon.edu 
Size and morphological features of seaweeds can have a major bearing on the benefits they provide to other species. Numerous invertebrates are dependent on seaweeds with varying morphological features, including the complex three-dimensional Macrocystis (Graham 2004), the compact spongy Codium (Trowbridge 1998; Bulleri et al. 2006), the fan-like broad thallus of Chondrus (Janiak and Whitlatch 2012), the crustose coralline algae Clathromorphum (Chenelot et al. 2011) and the calcareous rhodoliths (Foster 2001). Steller et al. (2003) reported that the total number of organisms supported by the coralline red algal rhodoliths significantly increased with both complexity (branching density) and space available (thallus volume) when compared with adjacent sand community. Thus, thallus size/volume can be a factor determining species richness and abundance in associated organisms.

Another morphological trait found in some algae is the presence of saccate or sac-like thallus that retains sea water when exposed to air during low tide. The saccate red alga Halosaccion glandiforme grows in clumps in the rocky intertidal areas along the Pacific coast of North America, ranging from the northern Aleutian Isles to southern California (Mondragon 2003). The plant has a short stipe, a discoid holdfast, and thalli measuring $3-4 \mathrm{~cm}$ in diameter; it grows to a length of 10-20 cm over the course of a year (Johnson 1994). This seaweed is commonly referred to as the sea sac because its thallus is a cylindrical hollow sac, partially filled with sea water and about a cubic centimeter of gas. Each thallus possesses 5-15 irregularly shaped pores, 10-200 $\mu \mathrm{m}$ in diameter, which allow water into and out of the thallus during exposure and immersion associated with tidal cycles (DePamphilis 1978; Vogel and Loudon 1985). When tides recede, water inside the thallus is retained. Such water reserves reduce desiccation and heating of tissue during periods of emersion (DePamphilis 1978). It has been reported in some field guides that the water-filled sacs of $H$. glandiforme are inhabited by a variety of invertebrates (Mondragon 2003; Lamb and Hanby 2005).

The role of this "sea sac" as a microhabitat for assemblages of small invertebrates has been virtually unexplored. In this study, for the first time, we note the presence of fauna found inside the saccate thallus of $H$. glandiforme. The objectives of this study were to: (1) quantify species richness and abundance (2) determine relationship between species richness/abundance and thallus/seawater volume using multiple regression, and (3) observe miscellaneous ecological interactions between taxa.

\section{Materials and methods}

Fronds of $\mathrm{H}$. glandiforme were collected from Cape Arago State Park in Charleston, Oregon $\left(43.3062^{\circ} \mathrm{N}\right.$; $124.3935^{\circ} \mathrm{W}$ ), USA, between July and September 2015, during low tide. During sampling, the short stipe was gently snipped using a scalpel while making sure the water-filled thalli were intact (Fig. 1). The seaweeds

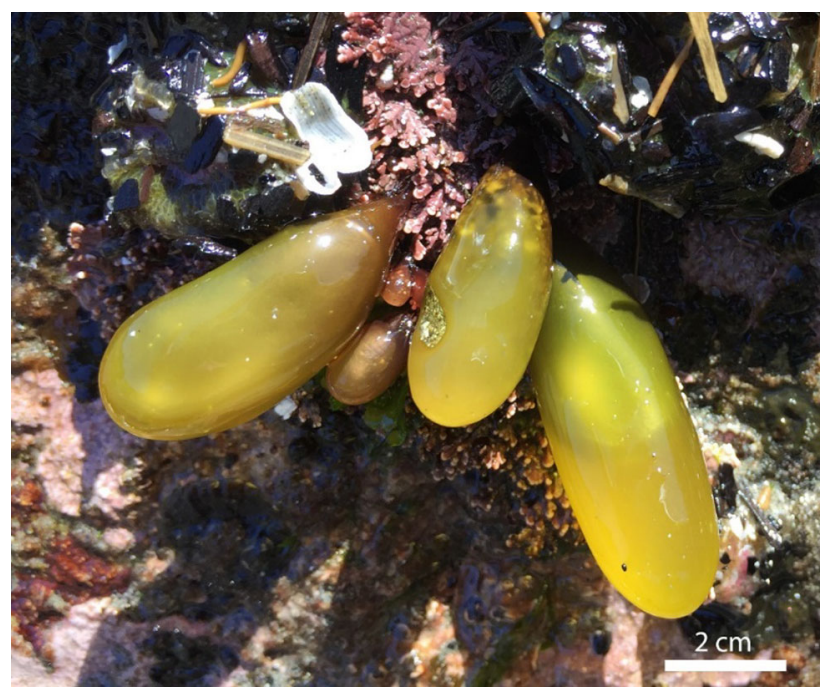

Fig. 1 Saccate thallus of Halosaccion glandiforme, tapering to a short stipe and attached to rocks with small discoidal holdfast. Note the oblong sac partially filled with seawater 
were transferred to plastic containers and transported to the laboratory at the Oregon Institute of Marine Biology for further analysis. Any damaged or dehydrated thalli were discarded and not analyzed in our study. All analyses were performed within $8 \mathrm{~h}$ of collection, which ensured quantifying and observing live fauna.

Using dissecting scissors, each thallus was carefully removed from the stipe. Assuming that each waterfilled thallus was roughly columnar in shape, we measured thallus volume using the formula $V=\pi r^{2} h$, where $h$ was the length and $r$ was the width at the widest point on the thallus. The thin seawater-filled sac was held vertically and the tip of the thallus was cut with a scissor. To measure seawater volume, the internal water was withdrawn using a calibrated $5 \mathrm{cc}$ wide mouth syringe. The content of the syringe was transferred into a watch glass and examined for fauna under a binocular stereo microscope (Olympus 10X). Most specimens were identified as close to their taxonomic level as possible using available taxonomic keys (Light and Carlton 2007) and their abundance noted. 10 min were spent observing interactions (if any) between the colonizers for each thallus. Other recognizable intra-thallus components (e.g., phytoplankton, detritus, molt remnants, etc.) were also noted for documenting additional ecological associations.

Multiple regression analyses were performed to determine the relationship between the richness and abundance of the invertebrate fauna and the size of the sea sacs, which included thallus size and fluid volume within each sac. A Kolmogorov-Smirnov test showed the data were not normally distributed, and further transformation did not normalize the data. However, linear regression/correlation might still be robust to nonnormality (McDonald 2014), so analyses were performed despite this violation. $P$ values $<0.05$ were considered statistically significant.

\section{Results}

We examined a total of 119 thalli of $H$. glandiforme. Table 1 lists the different types of invertebrates and their numbers associated with this alga. Of the 119 thalli inspected, 99 (83\%) were colonized by 845 individuals

Table 1 Richness, abundance (A), \% occurrence (O), mean occurrence (M.O.), range of invertebrate taxa, as well as copepod molts, within the saccate thallus of the red alga Halosaccion glandiforme

\begin{tabular}{|c|c|c|c|c|}
\hline Invertebrate taxa & A & $\mathrm{O}(\%)$ & M. O. & Range \\
\hline Nematoda & 598 & 52.9 & 9.5 & $1-107$ \\
\hline \multicolumn{5}{|l|}{ Order Chromadorida, Fam. Chromadoridae } \\
\hline \multicolumn{5}{|l|}{ O. Monhysterida, Fam. Xyalidae, Theristus sp. } \\
\hline \multicolumn{5}{|l|}{ Platyhelminthes } \\
\hline Class Turbellaria, Neoplana sp. & 3 & 2.5 & 1 & 1 \\
\hline \multicolumn{5}{|l|}{ Arthropoda } \\
\hline \multicolumn{5}{|l|}{ Crustacea } \\
\hline Acartia sp., Calanus sp. (Copepoda: Calanoida) & 183 & 29.4 & 5.2 & $1-65$ \\
\hline Copepod molt & 373 & 47.9 & 6.5 & $1-62$ \\
\hline Paradoxostoma sp. (Ostracoda) & 4 & 3.4 & 1 & 1 \\
\hline Mystacocaridada (Class Maxillopoda) & 3 & 2.5 & 1 & 1 \\
\hline Nauplius larvae & 45 & 17.8 & 2.8 & $1-14$ \\
\hline Cyprid larvae & 4 & 3.4 & 1 & 1 \\
\hline Arachnida & 3 & 2.5 & 1 & 1 \\
\hline \multicolumn{5}{|l|}{ Marine mites (Fam. Halacaridae) } \\
\hline \multicolumn{5}{|l|}{ Mollusca } \\
\hline Veliger larva & 1 & & & \\
\hline Unidentified bivalve & 1 & & & \\
\hline Rotifera & $\mathrm{nq}$ & 18.4 & & \\
\hline Foraminifera & 1 & & & \\
\hline
\end{tabular}

Percentages do not add to 100 , as occurrence refers to presence of each taxa inside thallus divided by total number of thalli examined $(N=119)$

$n q$ not quantified 

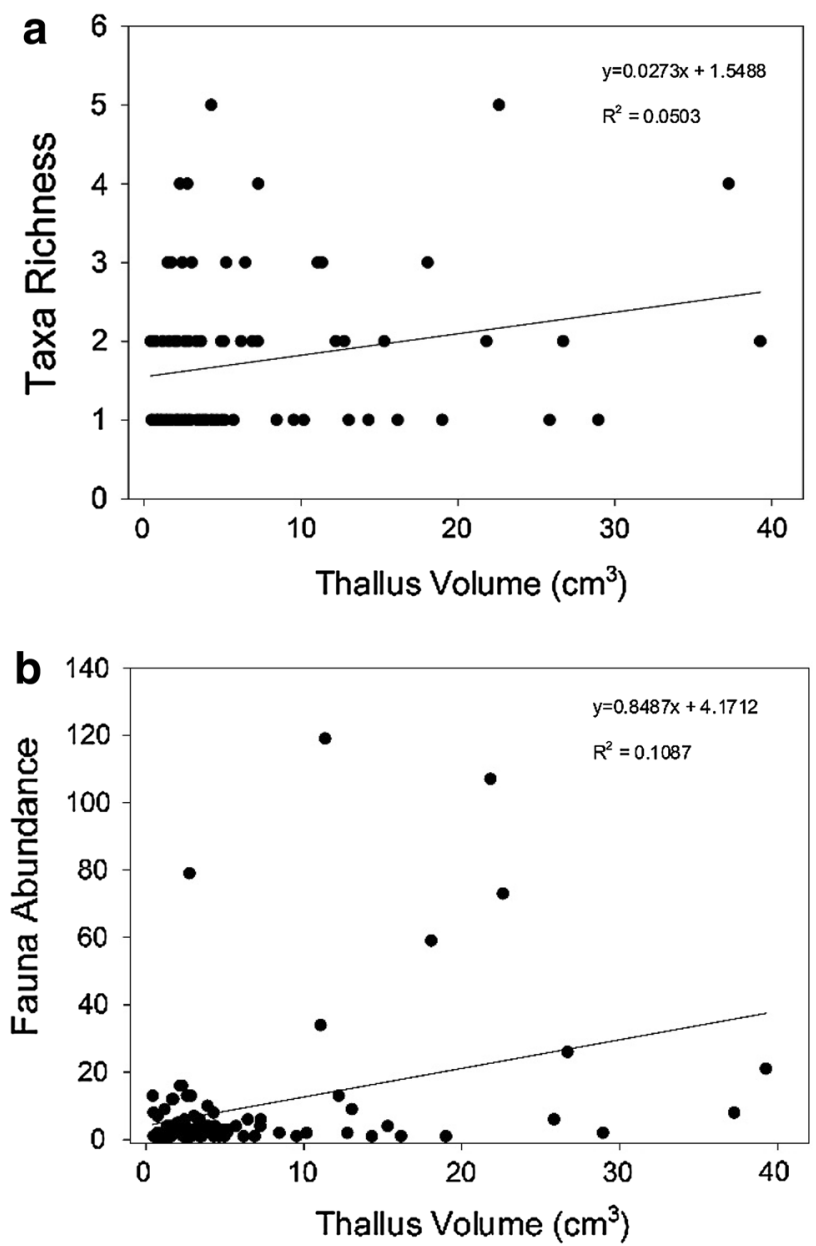

Fig. 2 Linear regression analysis of effect of thallus volume on a taxa richness, and $\mathbf{b}$ fauna abundance

belonging to 12 taxa in total. Up to 5 taxa and 119 individual invertebrates were found inside one sac. Table 1 also lists the percentage occurrence, mean occurrence, and range of all taxa associated with $H$. glandiforme.

Nematoda and Arthropoda were the dominant phyla; they made up over $92 \%$ of the total fauna. Nematodes were the most common inhabitants, occurring in $53 \%$ of thalli and constituting $70.8 \%$ of the total samples. Although the average number of nematodes per thallus was $\sim 10$, as many as 107 individuals were found in a single thallus. Copepods were the second most abundant group, occurring in $30 \%$ of thalli and comprising of $21.7 \%$ of all species. Nematodes and copepods were found to coexist in $26.1 \%$ of the samples. Copepods were occasionally found in various states of molting. The other lesser represented groups included ostracods, turbellarians, mites, and bivalves. Numerous copepod nauplii, a few barnacle cyprids, veliger larvae, rotifers, protozoans, diatoms, crustacean molt remnants, detritus, and sand particles were also found inside thalli.

Results of multiple regression analyses were separated in two groups: (a) thallus volume vs. taxa richness and abundance, and (b) fluid volume vs. taxa richness and abundance. The thallus volume and the intra-thallus fluid ranged from 0.42 to $39.27 \mathrm{~cm}^{3}$ (mean 6.02) and $0.1-8.6 \mathrm{~mL}$ (mean 1.10), respectively. Overall, larger thallus volume and greater intra-thallus fluid volume supported higher taxa richness and species abundance. Taxa richness was positively correlated with thallus volume $\left(F=4.66, P=0.03, R^{2}=0.05\right.$; Fig. $\left.2 \mathrm{a}\right)$ as was species abundance $\left(F=10.48, P=0.002, R^{2}=0.11\right.$; Fig. $\left.2 \mathrm{~b}\right)$. Furthermore, we found positive correlation between fluid volume and taxa richness $\left(F=4.25, P=0.04, R^{2}=0.05\right.$; Fig. 3a) as well as fauna abundance $\left(F=8.75, P=0.004, R^{2}=0.11\right.$; Fig. 3b).

A number of feeding interactions between colonizers were noted; they included herbivory, predator-prey interactions, and detritivory. Most of the invertebrates (e.g., copepods, ostracods, nematodes, mystacocaridads, rotifers) fed on diatoms and periphyton, some ingested other invertebrates (e.g., flatworm, nematodes, 

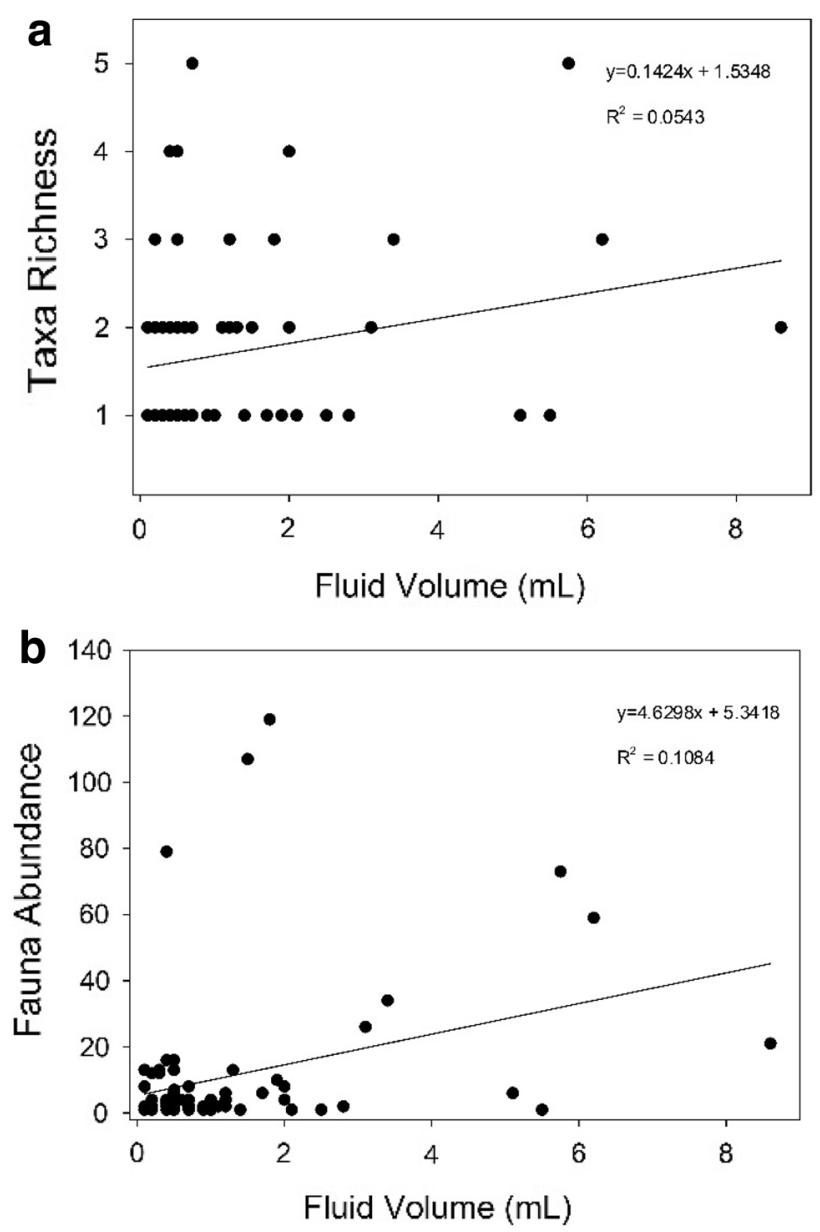

Fig. 3 Regression analysis of effect of fluid volume on a taxa richness $\mathbf{b}$ fauna abundance

copepods, mites), some consumed detritus (ostracods, bivalve, nematodes), and entrapped sediments (mostly nematodes). Nematodes were also found feeding on bacterial films on the copepod molts, which were common in our samples ( $\sim 48 \%$ occurrence, with up to 201 molts in a single thallus). As crustacean molts were common and nematodes are known detritivores (Heip et al. 1985, and references within), it was unsurprising to find a significant positive relationship between the presence of nematodes and molt remains inside the thallus ( $F=56.77, P<0.0001, R^{2}=0.40$; Fig. 4).

\section{Discussion}

The importance of seaweeds as habitats has been well studied for many rocky intertidal species; however, that has not been the case for the red alga $H$. glandiforme. Its fronds are annuals; new thalli appear in late winter and early spring, but degenerate after spore production during the following fall and winter (Johnson 1994). With pores as large as $200 \mu \mathrm{m}$, microfauna measuring $<200 \mu \mathrm{m}$ most likely enter the fronds via seawater medium and may leave the hollow sacs either during immersion or when the thalli degenerate at the end of the growing season. In this novel algal- invertebrate association study, we characterize this seaweed as a habitatforming species as it shelters multiple invertebrate groups inside its saccate thallus, and provides multiple benefits for its diverse invertebrate fauna, which in turn, may increase their survivorship and fitness.

Macroalgal traits such as size and morphological complexity can have a large effect on local populations and communities. The presence of multiple pores on the thallus of $H$. glandiforme allows seawater into and out of thalli during tidal cycles and facilitate faunal colonization. Our results show that thallus volume and the 


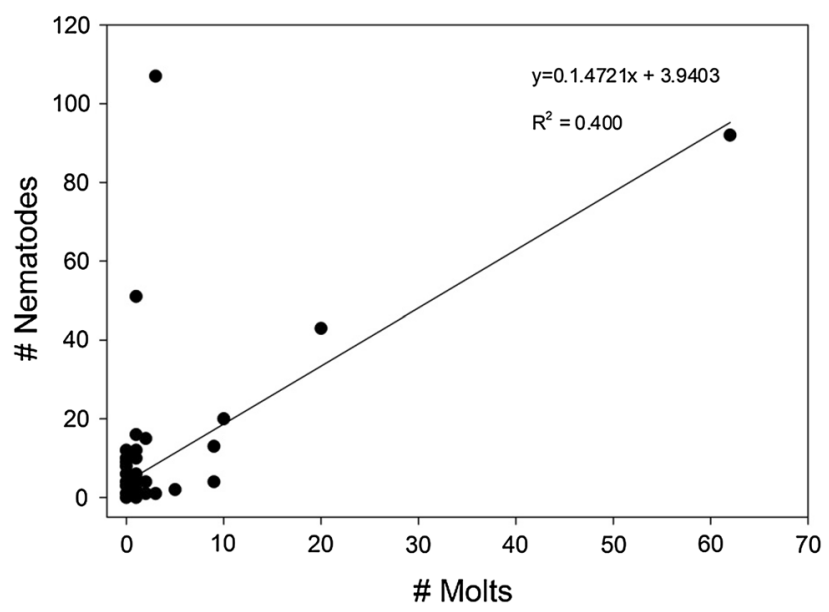

Fig. 4 Relationship between nematode abundance and presence of copepod molts

volume of seawater were important predictors of abundance and richness of invertebrates associated with this alga. Larger thalli possibly contained more resources, including sea water, which allowed them to shelter higher numbers of taxa and greater abundance of organisms. It is likely that bigger thalli have larger pores, which facilitate greater colonization opportunities. These thalli made the coexistence of species with different ecological necessities possible. Other studies have associated algal morphologies with species diversity and abundance. When given a choice between Gracilaria vermiculophylla and Ulva rigida, the architecturally more complex G. vermiculophylla supported higher species richness and diversity of associated macrofauna (Munari et al. 2015). Steller et al. (2003) also reported that the total organisms supported by rhodoliths, another group of benthic red alga, significantly increased with branching density and thallus volume.

We found nematodes to be the most abundant group in our samples. This is not surprising since they are considered to be among the most abundant organisms on earth. Marine roundworms inhabiting high-energy rocky shores are exposed regularly to changing tidal conditions. Being poor swimmers, they often remain suspended in the water column before re-entering the benthos as passive particles when tides recede; yet, nematodes are efficient in choosing algal habitats (Ullberg and Ólafsson 2003). Nematodes in our algal samples may have entered the saccate thallus via passive or active mechanisms.

The majority of the nematodes we found belonged to the family Chromadoridae (pers. comm. Ashleigh Smythe). In a related study at a Brazilian rocky coast, nematode biodiversity was related to the structural features of macrophyte habitats and the most abundant phytal nematodes were chromadorids (Da Rocha et al. 2006). Chromadorids are often associated with marine macrophytes (Trotter and Webster 1983; Pérez-García et al. 2015). Feeding experiments of the marine nematode Chromadora showed that diatoms and chlorophytes were preferred food items (Tietjen and Lee 1973). However, Moens and Vincx (1997) reported that many aquatic nematodes are in fact opportunistic feeders, which may change feeding strategies in response to available food. We also encountered nematodes belonging to the genus Theristus in our samples. This freeliving marine nematode group has been found in diverse habitats, including degraded algal beds (Olafsson et al. 2013) and exposed sandy beaches (Lee and Riveros 2012). Theristus is known to ingest suitably sized food particles like microalgae cells (Moens and Vincx 1997). Diatoms have been shown to be a prominent food resource for Theristus (Moens et al. 2014). Diatoms were abundant in our samples and nematodes were frequently observed ingesting them as well as other items inside the thalli.

We found a positive association between the presences of nematodes and remnants of copepod molts. Nematodes were observed feeding on the distinct bacterial films covering these molts. As substrate consumers, nematodes are known to ingest organic substrates along with their associated microflora and microfauna (Moens et al. 2006). Tietjen and Lee (1973) reported that Chromadora macrolaimoides, isolated from the collections present on the green alga Ulva intestinalis, consumed different types of bacteria.

Copepods were the second most abundant group in our samples. This too is not unexpected as they are considered to be one of the most abundant groups in the marine realm. Halosaccion glandiforme belongs to class Rhodophyceae and, according to Fahrenback (1962), rhodophyceans show higher assemblage of 
copepods than other algal groups. Although the exact reasons why red algae are preferred over brown algae are unknown, Fahrenback (1962) postulates that some red algal fronds are thick enough to accommodate these crustaceans and prevent their dislodgement. Whereas Fahrenback (1962) observed one harpacticoid copepod species (Diathrodes cystoecus) in sea sacs collected from Moss Beach, California, we found two genera of planktonic calanoids, Acartia sp. and Calanus sp. within the algal thalli. They were frequently observed to feed on diatoms and rotifers, which were plentiful in our samples. As omnivores, they were found to graze both on phytoplankton (Paffenhöfer and Lewis 1989) and protozooplankton (ciliates, heterotrophic dinoflagellates, flagellates), and rotifers (Stoecker and Egloff 1987).

In addition to serving as feeding grounds, $H$. glandiforme may also serve as a nursery habitats as gravid copepods and various larval groups were frequently observed. Copepods were found in various states of molting, implying their growth and development inside thalli. The presence of other associated taxa suggested that sea sacs may act as a refuge for multiple species, especially during periods of emersion. According to Lilley and Schiel (2006), habitat-forming species increases spatial complexity and help ameliorate stressful environmental conditions, thereby promoting a diversified assemblage of animals. It is obvious that the use of $H$. glandiforme as a habitat for invertebrates is multifaceted, as it provides refuge from physical stresses and predation, facilitates trophic interactions, and serves as nursery ground. As such, this macroalgae should be addressed in studies dealing with coastal biodiversity conservation.

Acknowledgements We are grateful to A. Smythe for identification of a few taxa. We thank A. Bhaduri for assistance in the field and two anonymous reviewers for their helpful comments on the manuscript. Laboratory space was provided by the Oregon Institute of Marine Biology in Charleston, Oregon. This work was funded by California State University Stanislaus Biology Research Committee and Faculty Development Mini-Grant Awards. The primary author acknowledges the support of A. Kohlhaas, K. Schoenly, M. Gerson, M. Fleming, P. Kelly, and C. Jantz on this project.

Open Access This article is distributed under the terms of the Creative Commons Attribution 4.0 International License (http:// creativecommons.org/licenses/by/4.0/), which permits unrestricted use, distribution, and reproduction in any medium, provided you give appropriate credit to the original author(s) and the source, provide a link to the Creative Commons license, and indicate if changes were made.

\section{References}

Bulleri F, Airoldi L, Branca GM, Abbiati M (2006) Positive effects of the introduced green alga, Codium fragile ssp. tomentosoides, on recruitment and survival of mussels. Mar Biol 148:1213-1220

Chenelot H, Jewett SC, Hoberg MK (2011) Macrobenthos of the nearshore Aleutian Archipelago, with emphasis on invertebrates associated with Clathromorphum nereostratum (Rhodophyta, Corallinaceae). Mar Biodiv 41:413-424

Da Rocha CMC, Venekey V, Bezerra TNC, Souza JRB (2006) Phytal marine nematode assemblages and their relation with the macrophytes structural complexity in a Brazilian tropical rocky beach. Hydrobiologia 553:219-230

DePamphilis C (1978) The resistance to damage due to desiccation in the intertidal alga Halosaccion glandiforme (Gmelin) Ruprecht. MS., Library of Friday Harbor Laboratories, Friday Harbor (Unpub)

Fahrenback WH (1962) The biology of a harpacticoid copepod. La Cellule 62:301-376

Foster M (2001) Rhodoliths: between Rocks and Soft Places. J Phycol 37:659-667

Graham MH (2004) Effects of local deforestation on the diversity and structure of southern California giant kelp forest food webs. Ecosystems 7:341-357

Heip CHR, Vincx M, Vranken G (1985) The ecology of marine nematodes. Oceanogr Mar Biol Ann Rev 23:399-489

Janiak DS, Whitlatch RB (2012) Epifaunal and algal assemblages associated with the native Chondrus crispus (Stackhouse) and the non-native Grateloupia turuturu (Yamada) in eastern Long Island Sound. J Exp Mar Biol Ecol 413:38-44

Johnson LE (1994) Enhanced settlement on microtopographical high points by the intertidal red alga Halosaccion glandiforme. Limnol Oceanogr 39:1893-1902

Lamb A, Hanby BP (2005) Marine life of the Pacific Northwest. Harbour Pub, Madeira Park, BC

Lee MR, Riveros M (2012) Latitudinal trends in the species richness of free-living marine nematode assemblages from exposed sandy beaches along the coast of Chile (18-42 $\left.{ }^{\circ} \mathrm{S}\right)$. Mar Ecol 33:317-325

Light SF, Carlton JT (2007) The Light and Smith manual: intertidal invertebrates from central California to Oregon. Univ of California Press, Berkeley

Lilley SA, Schiel DR (2006) Community effects following the deletion of a habitat-forming alga from rocky marine shores. Oecologia 148:672-681

McDonald JH (2014) Handbook of biological statistics, 3rd edn. Sparly House Publishing, Baltimore

Moens T, Vincx M (1997) Observations on the feeding ecology of estuarine nematodes. J Mar Biol Assoc UK 77:211-227

Moens T, Traunspurger W, Bergtold M (2006) Feeding ecology of free-living benthic nematodes. Freshwater nematodes: ecology and taxonomy. $\mathrm{CAB}$ International publishing, Cambridge, pp 105-131 
Moens T, Vafeiadou AM, De Geyter E, Vanormelingen P, Sabbe K, De Troch M (2014) Diatom feeding across trophic guilds in tidal flat nematodes, and the importance of diatom cell size. J Sea Res 92:125-133

Mondragon J (2003) Seaweeds of the Pacific Coast: common marine algae from Alaska to Baja California. Sea Challengers, Monterey, p 97

Munari C, Bocchi N, Mistri M (2015) Epifauna associated to the introduced Gracilaria vermiculophylla (Rhodophyta; Florideophyceae: Gracilariales) and comparison with the native Ulva rigida (Chlorophyta; Ulvophyceae: Ulvales) in an Adriatic lagoon. Ital J Zool 82:436-445

Olafsson E, Aarnio K, Bonsdorff E, Arroyo NL (2013) Fauna of the green alga Cladophora glomerata in the Baltic Sea: density, diversity, and algal decomposition stage. Mar Biol 160:2353-2362

Paffenhöfer G, Lewis KD (1989) Feeding behavior of nauplii of the genus Eucalanus (Copepoda, Calanoida). Mar Ecol Prog Ser $57: 129-136$

Pérez-García JA, Ruiz-Abierno A, Armenteros M (2015) Does morphology of host marine macroalgae drive the ecological structure of epiphytic meiofauna? J Mar Biol Oceanogr 4:1-7

Steller DL, Riosmena-Rodriguez R, Foster MS, Roberts CA (2003) Rhodolith bed diversity in the Gulf of California: the importance of rhodolith structure and consequences of disturbance. Aquat Conserv 13:5-20

Stoecker DK, Egloff DA (1987) Predation by Acartia tonsa Dana on planktonic ciliates and rotifers. J Exp Mar Biol Ecol 110:53-68

Tietjen JH, Lee JJ (1973) Life history and feeding habits of the marine nematode, Chromadora macrolaimoides Steiner. Oecologia 12:303-314

Trotter D, Webster JM (1983) Distribution and abundance of marine nematodes on the kelp Macrocystis integrifolia. Mar Biol 78:39-43

Trowbridge CD (1998) Stenophagous, herbivorous sea slugs attack desiccation-prone, green algal hosts (Codium spp.): indirect evidence of prey-stress models (PSMs)? J Exp Mar Biol Ecol 230:31-53

Ullberg J, Ólafsson E (2003) Free-living marine nematodes actively choose habitat when descending from the water column. Mar Ecol Prog Ser 260:141-149

Vogel S, Loudon C (1985) Fluid mechanics of the thallus of an intertidal red alga, Halosaccion glandiforme. Biol Bull 168:161-174

Wikström SA, Kautsky L (2007) Structure and diversity of invertebrate communities in the presence and absence of canopyforming Fucus vesiculosus in the Baltic Sea. Estuar Coast Shelf 72:168-176 